\title{
The Role of Ecotourism in the Reduction of Anthropogenic Load on Natura 2000 Territories throughout Latvia
}

\author{
Eriks Leitis, Faculty of Geographical and Earth Sciences, University of Latvia
}

\begin{abstract}
Ecotourism is able to contribute to biodiversity and to ensure the ecosystem function in Latvia through a complicated process of fulfilment of the established criteria for a valid ecotourism. The tourism flow in protected nature territories should be monitored, and the appropriate environmental management, education and a code of conduct need to be introduced. Ecotourism will serve for reducing the social and economic pressures on biodiversity and will promote responsible actions in support of environmentally friendly technologies and approaches. The areas selected for this study are the Natura 2000 territories that have undertaken the development of ecotourism facilities.
\end{abstract}

Keywords - Biodiversity, ecotourism, environmental management, protected nature territories

\section{INTRODUCTION}

Ecosystem services are essential to humanity in maintaining of life systems, supplying of natural materials and energy resources, as well as partly through absorbing of waste $[1,2,3]$. The protection of biodiversity is a difficult but essential process to ensure ecosystem services and to guarantee sustainable development. In modern society, economic activities increasingly tend to deplete natural resources and to degrade the environment, the restoration of which will ultimately be disproportionately expensive. In most cases, as global experience has shown, environmental degradation tends to be irreversible [4]. To avoid these problems and to develop a balanced approach between environmental protection and economic development, it is necessary to integrate such an instrument in order to reduce anthropogenic pressure on sensitive nature areas in particular and on the environment in general. Tourism is a growing industry and it is anticipated that in the future an increasing number of activities will be arranged in attractive, but highly-sensitive Natura 2000 areas. For this reason, an appropriate management system must be developed for Specially Protected Nature Territories to minimise the environmental impact caused by the tourist industry and others. Once scientific research has been conducted on environmental impact assessment and the capacity of ecosystem services, these activities need to be developed. Ecotourism in Latvia is seen as a possible opportunity for better nature conservation and for sustainable development. In accordance with the state law, there are 334 protected nature territories in the European category of Natura 2000 significance where tourism activities form an intensive part of daily life. This presents a particularly strong argument in favour of ecotourism taking a leading position in the minimization of the impact of industry on protected nature areas. The directions of planning and development in ecotourism, according to the definition of ecotourism as responsible travel to natural areas that conserves the environment and improves the well-being of local people [5], are characterised by the following principles: minimize impact; build environmental and cultural awareness and respect; provide positive experiences for both visitors and hosts; provide direct financial benefits for conservation; provide financial benefits and empowerment for local people; raise sensitivity to host countries' political, environmental, and social climate [6]. It should be added that the Latvian Ecotourism Development Strategy [7] is still the most complete ecotourism policy-planning document in our country and, as such, is the first comprehensive ecotourism planning document that takes into account both global experience and prospects for ecotourism in Latvia. The results of studies from around the world reveal that ecotourism, if properly planned and implemented, has a minimal impact and does not entail any long-term residue on wildlife in protected nature territories $[8,9,10,11]$. At present, the main document in the field of environmental policy in Latvia is the "Environmental Policy Strategy 2009 - 2015" which will continue to form the basis for environmental quality preservation and renewal, as well as for the sustainable use of natural resources, while limiting adverse impacts on the environment and human health. Latvia has ratified several international conventions and has passed many laws and regulations with regard to biodiversity protection in protected nature areas. Biodiversity protection is guaranteed by national legislation, including the Law on Specially Protected Nature Territories, the Law on the Conservation of Species and Biotopes, the Environmental Protection Law, the Cabinet Regulation No. 264 (16.03.2010) "General Regulations on Protection and Use of Specially Protected Nature Territories" and a number of other laws and Cabinet Regulations that determine aspects of governing, planning, management and environmental impact assessment procedures.

The purpose of this research is to analyse the environmental and tourism policy, as it influences the impact on biodiversity caused by tourism - one of the most intensive socioeconomic activities in the protected nature territories and to propose recommendations for sustainable management in the form of ecotourism, as well as for lessening the impact of anthropogenic footprint for these territories.

\section{METHODS}

This study includes the results of a series of interviews at local, regional and national levels in order to identify the general concerns of the government, local governments, academic institutions, the private sector, NGOs and local residents with respect to the issues of ecotourism. The questionnaire answers data compilation was used to measure the extent of fulfilment of ecotourism principles by the tourism organizers working in the protected nature territories in Latvia. Interviews and 
questionnaires were designed in such a way as to identify the role of tourism within the local economy and to evaluate prospects for the industry, improvement of environmental protection, reduction of the existing anthropogenic impact, as well as to elaborate a sustainable model for good ecotourism management in protected nature territories. The type of questions used for the interviews and questionnaires allowed the respondents to define their specific participation in the processes of tourism development, to indicate environmental risks caused by tourism, as well as to suggest possibilities for reducing these.

The interviewed respondents expected ecotourism to be a driving force for regional development, as well as to provide a conservation strategy for protected nature territories. A case study was carried out in Nature 2000 sites with regard to the current status of the ecotourism infrastructure and maintenance problems, ecotourism attractions, determination of tourist flows, motivations of interested parties, soil erosion, noise, waste disposal, environmental impact, administrative capacity and opportunities for local participation.

\section{RESULTS}

Volume 7

Latvia's natural environment is a part of its national heritage and represents a significant resource. Coastal wetlands, wet forests, pristine bogs, and natural habitats of animals are the features of national and international importance (Latvian National Development Plan 2007-2013). A large number of natural ecosystems have been preserved in Latvia. Protected natures territories Natura 2000 cover $12 \%$ (or 793265 hectares) of the territory of Latvia. Latvia's Specially Protected Nature Territories and designated Natura 2000 sites occupy almost $19 \%$ of its territory (Tab.1). Seven Specially Protected Marine Territories have recently been established and are accepted as a new category in the Latvia's nature conservation system (Source: Nature Conservation Agency of Latvia) The conservation process has been influenced by various climatic, geographic and soilrelated factors and traditions and a varying intensity of economic activities. Latvia is one of the countries in Europe with the richest biodiversity and an established tradition of nature conservation. The first strict nature reserve was designated in 1912. The terrestrial biodiversity and landscapes of Latvia are significantly enriched by the coastal area of the Baltic Sea.

TABLE 1

CATEGORIES OF PROTECTED NATURE TERRITORIES

\begin{tabular}{|l|l|l|l|}
\hline $\begin{array}{l}\text { Categories of protected nature } \\
\text { territories }\end{array}$ & $\begin{array}{l}\text { Number of protected nature } \\
\text { territories }\end{array}$ & $\begin{array}{l}\text { Number of Natura 2000 protected } \\
\text { nature areas (included) }\end{array}$ & Tourism and ecotourism opportunities \\
\hline Strict Nature Reserves & 4 & 4 & not permitted, excluding separate zones \\
\hline National Parks & 4 & 4 & high priority, excluding separate zones \\
\hline Biosphere Reserves & 1 & 1 & high priority, excluding separate zones \\
\hline Nature Parks & 42 & 37 & high priority \\
\hline Nature Monuments & 355 & 9 & permitted \\
\hline Nature Reserves & 259 & 237 & limited \\
\hline Protected Landscape Areas & 9 & 9 & high priority \\
\hline Protected Sea Territories & 7 & 7 & Permitted, excluding separate zones \\
\hline Micro-reserves & 1959 & 24 & limited \\
\hline Total & 682 territories + 2025 micro- & 332 & \\
\hline reserves & & \\
\hline
\end{tabular}

Source: Ministry of Environmental Protection and Regional Development of Latvia

http://www.varam.gov.lv/lat/darbibas_veidi/ipasi_aizsargajamas_dabas_teritorijas/natura_2000/

According to the Law On Specially Protected Nature Territories:

Strict Nature Reserves are territories untouched by human activities or nearly natural, in which territories unhindered development of natural processes shall be ensured in order to protect and study rare or typical ecosystems and parts thereof. Strict nature reserves shall have zones in which all natural resources are completely excluded from economic and other activities, there may be zones in which restricted economic, recreational, educational or other activities are permitted.

National Parks are broad areas which are characterised by outstanding nature formations of national significance, landscapes and cultural heritage landscapes untouched by human activities or nearly natural, a diversity of biotopes, abundance of cultural and historical monuments, and peculiarities of cultural environment. The main goals of national parks shall be nature protection, preservation of cultural and historical heritage, scientific research, organisation of education and recreation, which are restricted by the goals of the protection of nature and cultural environment.

Biosphere Reserves are broad territories in which landscapes and ecosystems of international significance are located. The goal of establishing biosphere reserves is to ensure the preservation of natural diversity and to promote sustainable social and economic development of the territory. The territory of biosphere reserves in conformity with protection and utilization goals shall be divided into functional zones depending on the permitted economic, recreation, educational or other types of activities.

Nature Parks are territories that represent the natural, cultural and historical values of a particular area, and that are suitable for recreation and education. Organisation of recreation and economic activities in nature parks shall be carried out by ensuring the preservation of the natural, cultural and historical values located in such parks. 
Nature Monuments are separate, isolated natural formations: protected trees, dendrological plantings, avenues, geological and geomorphological nature monuments and other natural rarities having scientific, cultural and historical, aesthetic or ecological value. In order to ensure the preservation of protected trees and stones and the possibility of visiting such objects, the territory within a radius of ten metres around stones and the territory under the crowns of trees, as well as within a radius of ten meters around them counting from the projection of the crown of a tree shall also be protected.

Nature Reserves are nature territories little transformed or transformed in varying degrees by human activities, which territories include habitats of specially protected wild plant and animal species, and specially protected biotopes.

Protected Landscape Areas are territories remarkable for original and diverse landscapes. The objectives of such territories shall be to protect and preserve characteristic landscape and such landscape elements, which are significant for ensuring ecological functions of protected species and biotopes, for the cultural environment and landscapes characteristic of Latvia and the landscape diversity, as well as to ensure the preservation of environment appropriate for recreation of society and for tourism, and environment friendly management.

Protected Sea Territories are locations in the territorial sea, exclusive economic zone or continental shelf of the Republic of Latvia, which are established for the protection of protected biotopes and specially protected species habitat, as well as migratory bird significant feeding and wintering places.

Individual regulations regarding protection and use of protected territories may be developed taking into account the specific peculiarities of the protected territory, as well as the goals and tasks for the establishment and protection thereof. The individual protection and use regulations of the protected territory shall regulate the types of permitted and prohibited activities in such territory, as well as if necessary its division into functional zones. In order to co-ordinate environmental protection, use of natural resources and the interests of regional sustainable development, to ensure the preservation of the natural value of the territory, as well as to ensure a favourable protection status for such specially protected species and such protected biotopes, the protection purpose of which such territory was established or shall be established, a natural or legal person may develop a nature protection plans for a protected territory. Protected territories may be divided into functional zones. Protected territories may be divided into the following functional zones: strict regime, regulatory regime, nature reserve, nature park, protection of landscape and neutral zone. National parks may also establish a cultural-historical zone. Closed seasons may be declared in protected territories. Visiting in protected territories for the purposes of recreation, tourism, ecological education and scientific research shall take place in accordance with general regulations of protected territories and with individual regulations on protection and use of each territory. Visits in protected territories shall be controlled by the administrative body of such territory. In order to co-ordinate nature protection and economic interests, upon a proposal of the responsible minister, an advisory council of the protected territory may be established, the by-laws of which shall be approved by the Cabinet, but personnel shall be approved by the responsible minister. Local governments may finance and perform the management of protected territories within the administrative territory thereof. Associations, foundations and local governments shall inform the Nature Protection Board regarding the planned management measures. State environmental control of protected nature territories, specially protected species and biotopes, management and protection of micro-reserves shall be exercised by the Nature Protection Board, in other fields - by the State Environmental Service, as well as other State institutions within the scope of their competence. The establishment, preservation, maintenance and administration of the protected territories shall be financed from the State budget and local government budget resources. Scientific research in protected territories shall be applied for with the Nature Protection Board. The Nature Protection Board shall organise and co-ordinate monitoring of the protected territories.

There are 18047 animal, 5396 plant and 4100 mushroom species in Latvia. Experts consider 907 species (about $3.3 \%$ ) to be rare and endangered, while 723 plant and animal species and 93 biotopes have been included in lists of specially protected species and habitats. The protection of species and habitats is assured in Specially Protected Nature Territories and at Natura 2000 sites and micro-reserves (Tab. 2 -3).

TABLE 2

NuMBER OF SPECIES AND NUMBER OF PROTECTED SPECIES

\begin{tabular}{|r|l|r|l|l|}
\hline $\begin{array}{l}\text { Total number } \\
\text { of species }\end{array}$ & Group & $\begin{array}{l}\text { Number } \\
\text { of species }\end{array}$ & $\begin{array}{l}\text { Number of } \\
\text { protected species }\end{array}$ & Source \\
\hline 62 & Mammals & 36 & 26 & http://www.lvgma.gov.lv/produkti/soe2001_lv/par/daba/fauna.htm [used 25.05.2011] \\
\hline 342 & Birds & 247 & 95 & http://www.putni.lv/saraksti/lvpsss.xls [used 25.05.2011] \\
\hline 7 & Reptiles & 4 & 3 & http://www.latvijasdaba.lv/rapuli/ [used 25.05.2011] \\
\hline 13 & Amphibians & 7 & 6 & http://www.latvijasdaba.lv/abinieki/ [used 25.05.2011] \\
\hline 17500 & Invertebrates & 17396 & 104 & http://www.lvgma.gov.lv/produkti/soe2001_lv/par/daba/fauna.htm [used 23.05.2011] \\
\hline 1735 & Seed plants and ferns & 1507 & 228 & http://www.latvijasdaba.lv/augi/[used 23.05.2011] \\
\hline 514 & Moss & 385 & 129 & http://biodiv.lvgma.gov.lv/cooperation/mezi/fol195495 [used 23.05.2011] \\
\hline 504 & Lichens & 444 & 60 & http://biodiv.lvgma.gov.lv/cooperation/mezi/fol195495 [used 25.05.2011] \\
\hline 4100 & Mushroom & 4038 & 62 & http://latvijas.daba.lv/augi_senes/senes/[used 25.05.2011] \\
\hline 25 & Charophytes & 19 & http://priede.bf.lu.lv/grozs/LU/LU_Bio_Raksti/2005/Zviedre.pdf [used 25.05.2011] \\
\hline & & &
\end{tabular}


TABLE 3

AREA OF NATURAL HABITAT TYPES AND QUALITY OF DATA ON AREA

\begin{tabular}{|c|c|c|c|}
\hline \multirow[t]{2}{*}{ Habitats } & \multicolumn{3}{|c|}{ Quality of data on area $\left(\mathbf{k m}^{2}\right)$} \\
\hline & good & moderate & poor \\
\hline Costal and halophytic habitats & 2 & 107 & \\
\hline Costal sand dunes and continental dunes & 14 & 609 & 1 \\
\hline Freshwater habitats & & & 824 \\
\hline Temp. heath and scrub, scleroph. scrub & & 1 & 14 \\
\hline Nat. and semi-nat. grassland formations & & 73 & 87 \\
\hline Raised bogs, mires and fens & & 1650 & 808 \\
\hline Rocky habitats and caves & & & 1 \\
\hline Forests & & 2643 & \\
\hline
\end{tabular}

Source: Nature Conservation Agency of Latvia http://www.daba.gov.lv/public/lat/

Maintaining the number of protected species, habitats and landscapes in Latvia is a priority issue. As a result of support from UNDP, the EU'S LIFE programme, EU structural funds and the Latvian Environmental Protection Fund, various conservation projects have been carried out and an infrastructure is being introduced to support ecotourism and sustainable tourism as well as environmental education in the Protected Nature Territories. Meanwhile, climate change, eutrophication and uncontrolled industrial development will cause further damage to biodiversity in the near future. As a result of climate change, a semi-enclosed sea structure and intensive shipping, invasive alien species pose an increasing risk for the marine ecosystems of the Baltic Sea. In order to avoid a threat to biodiversity, restrictions have been imposed on the cultivation of genetically-modified crops in Specially Protected Nature Territories. A recent increase in timber felling activities has already caused serious damage to forest ecosystems.

One of the dominating forms of conservation practices has been to protect pristine areas from the development caused by mankind. This approach has encountered many difficulties. The new paradigm argues for a diversity of management forms where many stakeholders are involved. The tourism industry is being increasingly probed with regard to its concordance with environmental protection practices and local community development, as well as upon the demand for ecotourism as one of the most environmentally friendly forms of human interaction within nature areas. Current and potential ecotourism activities may well serve to promote healthy nature conservation efforts in protected nature territories. Studies in several countries have shown that it can be achieved by proper notification that $52.6 \%$ of the local population have a positive perception of their area of natural and cultural protection measures that will ensure long-term economic viability, $81.6 \%$ are ready to attend the environmental education program, seeing it as a contribution to the development of ecotourism and its prosperity [12,9]. Protected area visitation is an important component of ecotourism, and, as such, must be sustainable. However, protected area visitation may degrade natural resources, particularly in areas of concentrated visitor activities, like nature trails and recreation sites [13,14]. Dependence on the local and traditional experiences in the field of nature conservation is important and consequently should be emphasized $[15,16]$.

Industrialized countries are generally characterized by their high and continually increasing demand for nature-based tourism experiences in protected areas. Therefore, high-level consumerism and an extremely high per-capita demand for human [urban] comforts during their trip leads to overexploitation of natural resources, destruction of ecosystems and loss of biodiversity. At the moment, Latvia has not yet encountered such a large influx of tourists that might pose any significant threat to the environment in protected nature territories. Besides, the particularly popular tourist spots, such as the Gauja National Park, the Slitere National Park and the Kemeri National Park are all able to accommodate the existing tourism flows which are well-managed and controlled. In evaluating the reserve of the environmental carrying capacity, it is important to consider the possibility of increasing a tourist flow to these areas, thus generating additional income for environmental protection efforts and, at the same time, promoting sustainable local development. In protected nature territories, the benefits of conservation include sustainable implementation of ecosystem services, watershed protection, and micro-climatic regulation, buffering belts, the harvest of medicinal plants, environmental education and many other possibilities.

Ecotourism is becoming very popular, especially in protected areas, where wildlife is concentrated and is easier to observe, but the consequences of associated disturbance have seldom be quantified in other way than in the short-term, making the sustainability of this activity untested. The environmental impact assessment has combined a historical, an empirical and an experimental approach to assess the long-, medium- and short-term consequences of disturbance to wildlife [8]. Local governments are constantly seeking to promote alternative models of tourism, such as ecotourism, which is regarded in Latvia as being the most viable option for the continued environmentally supportive economic development. The booming ecotourism industry may also have its negative effects on protected territories. In many cases, ecotourism activities are still insufficient to be able to contribute effectively to environmental management in protected nature territories. The role that ecotourism can play as a partner to a conservation strategy depends on the 
strategies, individual protection and use regulations and the nature protection plans designed for protected nature territories in which the parties involved share the costs, as well as the benefits of environmental services.

The most important reasons for an unsustainable ecotourism project were that the number of tourists was simply too high which was reported from over a third of all unsustainable case studies. In a way, successful ecotourism projects subsequently fall victim to their own success, if tourist numbers are not strictly controlled, or quotas are not clearly indicated [17]. The International Union for Conservation of Nature (IUCN, 2011) points out that tourism can create economic development opportunities as an alternative to the unsustainable use of biodiversity. A more specific mission is dedicated for ecotourism which according to the definition have to minimize or even avoid the most negative effects, and should be carefully planned, managed and controlled. There is some evidence to suggest that the carrying capacities for many protected areas have been reached and that ecotourism and the related environmentally-sound forms of tourism destinations are becoming increasingly more popular with an expected increase in growth rates projected at up to $15 \%$ per year, in comparison to conventional tourism. The increasing demand for nature-based ecotourism products may also influence the social structure of the local community and thus cause changes in infrastructure development in accord with tourism consumption patterns. Small-scale development at the local level seems to be most applicable for ecotourism, as it ensures sustainability and flexibility, promotes local participation and co-operation. Also, the application of environmentally friendly technologies within ecotourism projects is especially important as regards conservation measures in protected nature territories in which tourism activities take place. Ecotourism can play an important role in attracting of scientific support for conservation of endangered nature territories. Ecotourism can also help generate financial resources to help protect habitats and species and invest in the overall wellbeing of local people.

The priority issues for nature protection which are relevant to development of ecotourism are indicated in the following Latvian policy planning documents and strategies:

- Enlargement of Natura 2000 areas in accordance with scientific research and up-to-date information on species and habitats by 2012 ;

- Implementation of monitoring and information systems for Natura 2000 by 2012

- Elaboration and implementation of nature management plans by 2015;

- Ensuring the management of Specially Protected Nature Territories through the involvement of public authorities, municipalities, academic institutions, NGOs and the private sector by 2015 ;

- Development of an updated version of the National Biological Diversity Programme by 2012;

- Applied research on endangered species to evaluate the dynamics of their populations;

- Promoting the exchange of good practices, information, education in the areas of environmental and sustainable development and public awareness of nature conservation issues.

Source: Environment Policy Strategy (2009-2015) http://www.vidm.gov.lv/lat/dokumenti/ppd/?doc $=9338$

Nature capital, nature conservation plan and a nature restoration fund are key issues and as such are included in the draft Sustainable Development Strategy for Latvia to 2030 (www.latvija2030.1v). Protection and management of biodiversity are stipulated in the relevant legislation and policy planning documents: National Programme on Biological Diversity (2000), Guidelines on Environmental Monitoring Programme 2009-2012, Latvian Rural Development National Strategy Plan 2007-2013, Environment Policy Strategy (2009-2015).

\section{DISCUSSIONS}

The role of ecotourism within nature conservation processes has been much discussed in Latvia, as well as throughout the entire world. There is a genuine necessity to determine the path of ecotourism development and the relative expense of protection of biodiversity, as it impacts on the community and other ecotourism development activities. Nevertheless, human activity has contributed, over time, to an increase in species extinction - thus, it is necessary to consider each and every step in the planning of ecotourism, regardless of the mostly assuring fact that ecotourism is considered by many as being one of the most environmentally-friendly forms of peoplenature interaction. Ecotourism brings conservation and development together, both in theory and spatially, around a strong sustainability stance, which is associated with the concept of sustainable development. The common association of ecotourism with sustainable development marks a clear priority on conservation over development - running through the range of both eco-centric and formally anthropo-centric arguments in its favour - from a diverse spectrum of NGOs and individuals [18]. This study is based on the factors identified as necessary to protect biodiversity by means of conservation through ecotourism activities.

The questionnaire and interview processes assisted in the gathering of information on respondent attitudes towards mass tourism and environmentally-friendly tourism, on consumer patterns and on the preferred comfort level - these all provide important details for the development of a valid ecotourism policy.

Ecotourism is characterized by three basic principles: it occurs in the natural environment, it should include sustainability principles and practices, and it must be built on a strong educational component [19]. One of the ongoing subpractices in the field of ecotourism, from both academic and industry perspectives, is the development of definitions [20] and terminologies. In terms of ecotourism and the definition of its principal concept, data from the surveys carried out, during this research process throughout the protected nature territories, revealed that only a few of the tour operators fully understood the essential philosophy of ecotourism. It has been recognized, over long-term discussions and debates, that a genuine perception and comprehension of the principles and mission of ecotourism is still a problem in Latvia - even among tourism professionals. A credible ecotourism must be 
firmly based on the scientifically determined ecological principles that precisely define the ecosystem's integrity. Such thus established tolerance should then be the fundamental measure against which all ecotourism products are monitored [21]. Conservation biology, ecotourism, and volunteer tourism have become subjects of serious academic study only within the last three decades. Ecotourism has the goal of generating income from nature-based attractions, aiming to support protected nature areas and local communities, and creating educational experiences for tourists. Another potential benefit from ecotourism is emerging through volunteerism. This model should, however, be broadly applicable in the majority of geographic regions. As a result of this, there is clearly the existence of a great potential to strengthen co-operation between ecotourism and broader scientific research efforts [22].

Though ecotourism creates economic incentives for conservation efforts, the increased attention to and attendance at protected nature territories, nevertheless, does alter the natural environment and affects local communities. In some cases, ecotourism may even be found to be in contradiction to the needs of particular species and habitats, as the majority of ecotourists attracted by the desire for a deeper experience do, however, continue to encroach upon the living space of birds and other wild animals, thus causing many negative impacts on protected species. It has become common to assert that implementation of successful ecotourism projects as a strategy for sustainable development in rural communities must include local people as central planners and decision-makers [23]. The population size and diversity of animal species tends to decrease in areas that are frequently visited by tourists especially near heavily used nature trails and attractions. However, there have, to date, been only a few studies undertaken with the purpose of determining whether ecotourism activities in protected areas are achieving the goals and expectations to protect the environment and, at the same time, contributing to the well-being of local communities. This is a still further research task for activities on ecotourism in Latvia.

A critical approach to ecotourism is essential, if it is to be harnessed for the conservation of habitats and species. Ecotourism will not be significantly different from conventional tourism, unless it is appropriately managed and controlled [24,25]. There is a persistent effort to understand the socio-cultural and ethical impacts of ecotourism $[26,27,28,29]$. It is quite typical that products designed to be of low-impact at the tourist destination are frequently to be found throughout the ecotourism sector, in contrast to other types of tourism. These products include and support the use of renewable energy sources and various energy-saving techniques, environment-friendly transport options, materials re-use and recycling, and facilities construction using only local materials [30]. There are many eco-friendly technologies and approaches and samples of environmentally friendly buildings sewage water treatment systems, heat pumps, solar panels, biogas generators, windmills are now gradually being introduced in ecotourism practice throughout Latvia $[31,32,33,34]$. It is necessary to undertake in-depth analytical studies of all such pilot-enterprises which focus on the integration of an environmentally-friendly infrastructure and production, and, thus, to find out which factors promote or hinder the processes of the green economy, all of which are very important for ecotourism throughout the entire country and tourism development in general. Ecotourism is not merely an economic 'tool' for conservation, but also the cause of new values and social relations. Among conservationists, ecotourism has been described as a potentially good way to use markets as direct economic incentives to protect biodiversity, 'watchable wildlife', and scenic landscapes [35].

When an area is granted a nature protection status, its residents often have to reconsider their local development alternatives and sustainable 'traditional' or new and appropriate activities because of the limitations on industrial or agricultural performance and in order to meet the requirements of conservation. Ecotourism in protected nature territories has already captured the attention of many sectors in Latvia. There are many great expectations on what it is that ecotourism can produce, as well as no fewer concerns about its pitfalls. Survey respondents from all sectors agreed that ecotourism is compatible with conservation efforts and that it has the capacity to increase the wellbeing of local communities and is a viable conservation strategy in Latvia. Moreover, ecotourism is being seen as an emerging potential local, national and international tourism market in Latvia. At present, the economic value of the ecotourism market niche that would be able to be captured by Latvia is quite insignificant. Most protected nature territories do not yet generate enough financial resources to cover their maintenance. Revenues are heavily dependent on the area's uniqueness, which is usually internationally recognized through its accessibility and marketing activities. Accordingly, revenues received through entrance fees are mostly insufficient. The economic potential of ecotourism remains largely unrealised so far. Many protected nature territories do not charge admission fees at all. Local communities have to participate actively in these processes, if they wish to receive a share of the financial benefit [36]. A precise estimate of the ecotourism's fiscal turnover is difficult to be identified as yet, since there is no consistent separation of eco-, nature-, culture tourism, and the motivations to travel are often many and varied. The existing statistical database of the necessary information is poor, and relevant information is difficult to obtain. The maintenance of protected nature territories is most often supported by the state budget. It is possible to combine the maximization of economic benefits and to reduce the pressure on ecosystems. Admission fees are a means to keep the number of visitors within an ecosystem's human visitor absorption capacity and / or to limit growth rates. Effective planning, management and control are pre-conditional for the establishment of a sound relationship between protected areas and all-encompassing ecotourism benefits. The soliciting of donations from ecotourists may yet be another way to increase revenues. Many tourists will pay voluntarily and additionally, if they can see that they are genuinely able to contribute to the preservation of nature. Ecotourism operators must be proactive and co-operative within the protected nature territories and should be involved in all aspects, including political, legal, economic, social and environmental ones, and they should re-invest a part of their income to the protected nature territories being utilised by their business activities. 
Environmental guiding is also one of the key issues. Guides are able to monitor and control visitors' behaviour as necessary in the protected nature territories. There is a large network of environmental guides throughout Latvia, and it is well utilised in the ecotourism practice. However, many of the survey respondents pointed to the shortage of specific regulations and guidelines for the implementation of ecotourism practices in local communities. The Nature Conservation Agency of Latvia oversees the implementation of the nature protection policy throughout Latvia and maintains a database (geographical location, quantitative and qualitative status, etc) of protected plants species, habitats and micro-reserves. This serves well for the ecotourism quality product improvement.

However, the database on habitats and species has been compiled on the basis of fragmentary research. More modern data collection methods and methodological improvements are required to improve efficiency in this area. Governments can always pass more laws and regulations to prevent the further abuse of a deteriorated environment and, thus, they have a unique responsibility as coordinators and supervisors of conservation programs and polices, but the actual application of conservation practice is developed largely under the auspices of local governments, private enterprises and NGOs.

\section{CONCLUSIONS}

It should be recognised that ecotourism promotes sustainable development in general, and conservation of biodiversity in particular. This form of environmentally sound tourism is able to carry out projects demonstrating good environmental management, social responsibility, sustainable economics and to provide a positive example for the entire tourism industry, not only in protected nature territories, but throughout the country as a whole. More in-depth exploration of ecosystem services is recommended, and this should be included as a part of the ecotourism value system for Natura 2000 sites. Biodiversity and ecosystems have essential values, which are rarely taken into account in Latvia. This is due to the lack of a market for ecosystem services, as well as to questionable government incentives for land use policies. Direct human and wildlife interaction and exposure limits must be carefully balanced in order to minimize the effect of the presence of visitors, while ensuring a sufficient cognitive richness and diversity for visitors, which is often the major purpose and mission of their trip.

Ecotourism, with particular emphasis on further research and environmentally-friendly technologies, should become an effective tool to reduce anthropogenic pressure in protected nature territories. It is important to expand government and local government, public and private sector cooperation by involving the scientific sector so as to improve the level of qualitative indicators of environmental and tourism policies in order to promote ecotourism at large. Direct revenues from ecotourism that are re-allocated to protected nature areas are insignificant at the moment and need to be increased. Therefore, the necessary mechanisms for direct transfer of financial resources generated by ecotourism, to support nature conservation and the wellbeing of local communities, should continue to be established and promoted. Positive examples of ecotourism are still rare. The constructive development of ecotourism in Latvia is dependent on successful strategies to introduce appropriate installations, to inform and educate managers, entrepreneurs, visitors and local residents, and to manage and control the area efficiently according the accepted and understood principles of ecotourism.

\section{REFERENCES}

1. Kḷavin̄š, M., Nikodemus, O., Seglin̦š, V., Melecis, V., Vircavs, M., Āboliṇa, K., Kḷaviṇa, M. red., Vides zinātne,: Rīga, Latvijas Universitātes apgāds, 2008. 599 p.

2. Melecis, V. Ekosistēmu pakalpojumi. In: Vide un ilgtspējīga attīstība. M.Kḷaviņa un J Zaļokšņa red. Rīga : Latvijas Universitātes Akadēmiskais apgāds, 2010, p. 29-68.

3. Suzuki, D. The Sacred Balance. Toronto: David Suzuki Foundation, Greystone Books, 1997. 259 p.

4. Millennium Ecosystem Assessment (2005) Ecosystems and Human Well being: Synthesis. World Resources Institute, Island Press, Washington, $\quad$ DC., $155 \quad$ p. http://www.millenniumassessment.org/documents/document.356.aspx. pdf

5. TIES, Our Misson (2009) The International Ecotourism Society http://www.ecotourism.org/site/c.orLQKXPCLmF/b.4835251/k.FF11/ Our_Mission_The_International_Ecotourism_Society.htm

6. TIES, Our Story (2011) The International Ecotourism Society http://www.ecotourism.org/site/c.orLQKXPCLmF/b.4835255/k.F912/ Our_Story__The_International_Ecotourism_Society.htm

7. Latvijas ekotūrisma stratēgija. Rīga, Vides aizsardzības un reǵionālās attīstības ministrija, 2001.105 p.

8. Guillemain, M., Blanc, R., Lucas, C., Lepley, M. Ecotourism disturbance to wildfowl in protected areas: historical, empirical and experimental approaches in the Camargue, Southern France. Biodiversity and Conservation, 2007, N16, p. 3633-3651.

9. García-Frapolli, E., Ayala-Orozco, B., Bonilla-Moheno, M., Espadas-Manrique, C., Ramos-Fernández, G. Biodiversity conservation, traditional agriculture and ecotourism: Land cover/land use change projections for a natural protected area in the northeastern Yucatan Peninsula, Mexico. Landscape and Urban Planning, 2007, N 83, p.137-153.

10. Krider, R.E., Arguello, A., Campbell, C., Mora, J.D. Trait and Image Interaction in Ecotourism Preference. Annual Tourism Research, 2010, N 37(3), p. 779-801.

11. Perkins, H., Grace, D.A. Ecotourism: supply of nature or tourist demand? Journal of Ecotourism, 2009, N 8(3), p. 223-236.

12. Pipinos, G., Fokiali, P. An assessment of the attitudes of the inhabitants of Northern Karpathos,Greece: towards a framework for ecotourism development in environmentally sensitive areas. An ecotourism framework in environmentally sensitive areas. Environment, Development and Sustainability, 2009, N 11, p. 655675.

13. Farrell, T., Marion, J. Identifying and assessing ecotourism visitor impacts at eight protected areas in Costa Rica and Belize. Environmental Conservation, 2001, N 28 (3), p. 215-225.

14. Puustinen, J., Pouta, E., Marjo Neuvonen, M., Sievänen, T. Visits to national parks and the provision of natural and man-made recreation and tourism resources. Journal of Ecotourism, 2009), N 8:1, p. 18-31.

15. Morris, C. Negotiating the boundary between state-led and farmer approaches to knowing nature : An analysis of UK agri-environment schemes. Geoforum, 2006, N 37, p.113-127.

16. Visser, M., Moran, J., Regan, E., Gormally, M., Skeffington, M. The Irish agri-environment: How turlough users and non-users view converging EU agendas of Natura 2000 and CAP. Land Use Policy, 2007, N 24, p. 362-373.

17. Krüger, $\mathbf{O}$. The role of ecotourism in conservation: panacea or Pandora's box? Biodiversity and Conservation, 2005, N 14, p. 579600.

18. Butcher, J. Natural Capital and the Advocacy of Ecotourism as Sustainable Development. Journal of Sustainable Tourism, 2006, N 14:6, p. 629-644.

19. Fennell, D., Nowaczek, A. Moral and empirical dimensions of humananimal interactions in ecotourism: deepening an otherwise shallow pool of debate. Journal of Ecotourism, 2010, N 9: 3, p. 239-255. 
20. Fennell, D. A. Content Analysis of Ecotourism Definitions. Current Issues in Tourism, 2001, N 4:5, p. 403 -421.

21. Tyler, D., Dangerfield, J. Ecosystem Tourism: A Resource-based Philosophy for Ecotourism. Journal of Sustainable Tourism, 1999, N 7: 2, p.146-158.

22. Brightsmith, D., Stronza, A., Holle, K. Ecotourism, conservation biology, and volunteer tourism: A mutually beneficial triumvirate. Biological Conservation, 2008, N 141, p. 2832 - 2842.

23. Fletcher, R. Ecotourism discourse: challenging the stakeholders theory. Journal of Ecotourism, 2009, N 8: 3, p. 269-285.

24. Zografos, Ch., Allcroft, D. The Environmental Values of Potential Ecotourists: A Segmentation Study, Journal of Sustainable Tourism, 2007, N 15:1, p. 44-66.

25. Buckley, R. Environmental Inputs and Outputs in Ecotourism: Geotourism with a Positive Triple Bottom Line? Journal of Ecotourism, 2003, N 2: 1, p. $76-82$.

26. Weaver, D., Lawton, L. Twenty years on: The state of contemporary ecotourism research. Tourism Management, 2007, N 28, p. 1168-1179.

27. Wurzinger, S., Johansson, M. Environmental Concern and Knowledge of Ecotourism among Three Groups of Swedish Tourists. Journal of Travel Research, 2006, N 45, p. 217- 226.

28. Nowaczek, A., Smale, B. Exploring the predisposition of travellers to qualify as ecotourists: the Ecotourist Predisposition Scale. Journal of Ecotourism, 2010, N 9: 1, p. 45-61.

29. Hovardas, T., Poirazidis, K. Evaluation of the Environmentalist Dimension of Ecotourism at the Dadia Forest Reserve (Greece) Environmental Management, 2006, N 38, p. 810-822.

30. Hunter, C., Shaw, J. Applying the ecological footprint to ecotourism scenarios. EnvironmentalConservation, 2006, N 32 (4), p. 294-304.

31. Blumberga, D. Siltuma sūkņi. Rīga : Rīgas Tehniskā Universitāte, 2008.140 p.

32. Blumberga, A.,, Blumberga, D.,, Klaviňš, M.,, Rošā, M., Valtere S., Blumbergas D. red., Vides tehnologijas, Rīga : Latvijas Universitāte, 2010. 212 p
33. Kḷaviņš, M. Vides piesārņojums un tā iedarbība. Rīga: Latvijas Universitātes Akadēmiskais apgāds, 2009.198 p.

34. Tilgalis, $\overline{\mathbf{E}}$. Notekūdeņu savākšana un attīrī̌sana. Jelgava: Latvijas Lauksaimniecības Univesitāte, 2004. 239 p.

35. Stronza, A. The Economic Promise of Ecotourism for Conservation. Journal of Ecotourism, 2007, N 6: 3, p. 210 -230.

36. Anderson, W. Promoting ecotourism through networks: case studies in the Balearic Islands. Journal of Ecotourism, 2009, Vol. 8, N 1, p. 5169.

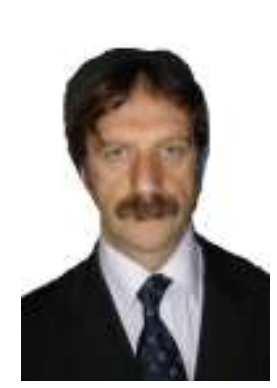

Eriks Leitis, senior consultant, Department of Nature Protection of the Ministry of Environmental Protection and Regional Development of Latvia. Eriks Leitis has been part of the research unit of the Institute of Restoration, Ministry of Culture of Latvia (1986 - 1993), researcher and lecturer at the Chair of Environmental Management, University of Latvia since 1995. The main research area is ecotourism in protected nature territories and heritage in Latvia. He has participated in different local and international projects related to sustainable tourism development, as well as is author of more than 30 publications and teaching materials. He has Historian Diploma (1985) and after his doctoral studies of environmental science currently is working on his $\mathrm{PhD}$ thesis "Ecotourism in Latvia: Problems and Solutions for Promotion of Sustainable Tourism Industry" at the Faculty of Geography and Earth Sciences, University of Latvia.

Address: Peldu 25, LV-1494, Riga, Latvia

Phone: +37129544330

E-mail: eriksl@lanet.lv

Ēriks Leitis. Ekotūrisma nozīme antropogēnās slodzes mazināšanā Natura 2000 teritorijās Latvijā

Pētījuma mērkis ir izzināt ekotūrisma iespējas antropogēnās slodzes mazināšanā aizsargājamās dabas teritorijās. Tūrisms kā pasaulē viena no lielākajām augošajām industrijām radot arvien jaunus produktus un aptverot arvien lielākas neskartās un jūtīgās dabas teritorijas var izraisīt tām palielinātus riskus. Ekotūrisms, kas pēc savas definīcijas ir videi viena no visdraudzīgākajām un sociāli atbildīgākajām tūrisma formām, ja atbilstoši plānots un realizēts, var kḷūt par instrumentu bioloǵiskās daudzveidības saglabāšanā un ekosistēmu funkciju nodrošināšanā, tai pašā laikā nodrošinot tūrisma radītās ietekmes uz vidi samazināšanu, ekotehnoloǵiju pielietošanu, vides izziņas, izpētes un izglītības iespējas. Liela nozīme ekotūrismam ir pašvaldību ilgtspējīgās attīstības veicināšanā palielinot vietējo iedzīvotāju uzñēmējdarbību saskañā ar labāko pieejamo vides aizsardzības praksi. Latvija īpaši izcel̦as ar labi saglabāto bioloǵisko daudzveidību un tās aizsardzības tradīcijām valsts un pašvaldības institūcijām sadarbojoties ar zinātnes sektoru, nevalstiskajām organizācijām un sabiedrību kopumā. Pētījuma rezultātā radās secinājumi par ekotūrisma pozitīvo lomu Natura 2000 un citu īpaši aizsargājamo dabas teritoriju aizsardzībā Latvijā videi draudzīgo tehnoloǵiju un pieeju ieviešanā tūrismā kopumā. Nozīmīgs ir arī Latvijas ekotūrisma potenciāls starptautiskajā tūrisma apritē. N̦emot vērā, ka ekotūrisms mūsu valstī atbilstoši starptautiski atzītajai definīcjai ir attīstības sākumā, ir jāsecina ka turpmākie pētījumi šajā jomā ir īpaši nozīmīgi pilnveidojot profesionālo izglītību un nodrošinot zinātnisko pamatu ekotūrisma plānošanas un realizēšanas procesiem.

\section{Эрик Лейтис. Роль экотуризма в снижении антропогенной нагрузки в территориях Натура 2000 в Латвии}

Целью исследования является изучение возможности экотуризма в снижении антропогенной нагрузки в охраняемых природных территориях. Туризм как одна из крупнейших растущих мировых отраслей промышленности в создании более новых продуктов и охватывающие все более и более заповедные и чувствительные природные территории может привести к их повышенному риску. Эко-туризм, который по определению является одним из самых экологически чистых средств и социально ответственных форм туризма, если соответственно планируются и осуществляются, может стать инструментом для сохранения биоразнообразия и экосистемных функций, обеспечивая при этом снижение воздействия туризма на окружающую среду, применение экологических технологий и также исследовательские, познавательные, образовательные возможности. Важную роль экотуризм имеет в процесе устойчивого развития на местном уровне способствуя увеличению местного предпринимательства в соответствии с наилучшей доступоной природоохранной практикой охраны среды. Латвия отличается своим хорошо сохранившимся качеством биоразнообразия и традициями её защиты, где в сотрудничестве принимают участие государственные институции, местные самоуправления, научный сектор, неправительственные организации и общество в целом. Исследование привело к выводам о положительной роли экотуризма в сохранении Натура 2000 и других природоохранных территорий в Латвии, во внедрении эко-технологий и подходов к реализации туризма в целом. Также важным является потенциал эко-туризма Латвии на мировом рынке бизнеса международного туризма. Учитывая, что эко-туризм в нашей стране в соответствии с международно признанной дефиницией находится в начале развития, следует сделать вывод, что дальнейшие исследования в этой области имеют особое значение для улучшения профессионально-технического образования и обеспечения научной основы для процессов планирования и реализации эко-туризма. 